\begin{tabular}{ccc}
\hline INTERnals & $\begin{array}{c}\text { INTEUSTRIAL } \\
\text { ORGANIZATIONAL LEADERSHIP }\end{array}$ \\
MANAGEMENT \\
\hline
\end{tabular}

\title{
Investigating the relationship between transformational leadership and organizational commitment of high school teachers in Germi
}

\author{
Mohammad Feizi $^{1}$, Esmael Ebrahimi ${ }^{2}$, Nouraddin Beheshti ${ }^{3}$ \\ 1-Department of Management, Meshkin shahr Branch, Islamic Azad University, Meshkin shahr, Iran \\ 2, 3- Department of Management, Germi Branch, Islamic Azad University, Germi, Iran
}

\begin{abstract}
Keywords:

Transformational Leadership, Organizational Commitment,

Secondary School Teachers

This study examines the relationship between transformational leadership style and organizational commitment of Germi's secondary school teachers in academic year 20112012. Four-hundred secondary school teachers consisted the statistical population of the study. The determined sample size by the Cochran formula was 196. The sample was selected through simple random sampling. The data obtained through Bass and Avolio's

Correspondence: multifactor leadership questionnaire (1996) and Porter's organizational commitment questionnaire (1974). The results showed that there was a significant positive correlation

Department of Management, Meshkin shahr Branch, Islamic Azad University, Meshkin shahr, Iran m_feizei@yahoo.com between transformational leadership and organizational commitment of teachers. In addition, stepwise regression analysis demonstrated that among the components of transformational leadership, the idealized influence had the greatest impact on organizational commitment of teachers.
\end{abstract}

(C)AIMI Journals

\section{Introduction}

For a long time, leadership has been the focus of attention of the public and researchers. The extensive attractiveness of leadership is most likely to be due to its mysterious process that can be seen in all-people's lives. In many investigations, the behavioral scientists have tried to identify how a leader can influence his/her followers and achieve group goals based on 
characteristics, abilities, behaviors, sources of power, and aspects of the situation (Yukl, 2003).

If leadership is a function, it should be considered as indispensable part of management whose existence depends on a number of skills regarded as people's leadership style in achieving specific goals. Leadership is one of the terms that there is no consensus on it. As Stogdil (1974) has put, the number of definitions of leadership is equal to the number of people who have tried to define it; however, most of the definitions offered, hinge upon influence.

The new century has brought a new wave of change with itself. The environment surrounding organizations has become more dynamic than before and has caused organizations to find ways for dealing with this dynamicity. In such an environment, in order for the organizations to gain success and survive, it is essential that organizations head toward flexibility, dynamicity and evolution, and avoid stagnation. Modern organizations need leaders with attractive personality traits and great charisma, strong influence, and broad vision who create commitment and enthusiasm in their subordinates to make optimal use of their talents and abilities in achieving organizational goals. Today, these leaders are called transformational leaders.

Burns pioneered the transformational leadership approach versus transactional leadership in 1978. He believed that transactional leaders have relationship, i.e., exchanging one thing with another with subordinates, but transformational leaders are those who benefit from brilliant insights and charismatic personality traits, and in virtue of those characteristics create high level of needs, motivation, values and morale in their subordinates.

Schermerhorn (1997), also, stated that the concept of transformational leadership describes people who take advantage of their charisma and characteristics associated with it to stimulate their subordinates' hopes, aspirations, and change organizational systems, aiming at achieving goals with high performance. He has also pointed out that transformational leadership inspires the subordinates to achieve superior performance in terms of innovation and large scale change (Javdani, 2011).

Nowadays, in many countries, researchers and scholars in the field of organizational behavior, based on some empirical evidence and findings of studies to date, hold that the most appropriate way of management and leadership in organizations, including educational organizations, is transformational leadership style. They also believe that these leaders thanks to their unique personality traits, charisma, influence, and broad vision can create necessary 
commitment and passion in subordinates to bring their talents and potential into play with the purpose of attaining organizational goals.

Bass and Avolio (1992) argue that transformational leaders in contrast to transactional leaders have greater advantages and are more successful. As an example, they refer to the research undertaken on the authorities of military affairs in the United States of America, Canada, and Germany indicating that transformational leaders were more successful and efficient than transactional leaders (Robbins, 1998).

It is, also, worth mentioning that employees can produce stunning performance when they regard the work as their own, have mental attachment to organization, and discover their identity in the organization. In other words, they are of high organizational commitment. Since committed employees are more disciplined in their work, and spend longer time in organizations working hard, it seems rational to produce excellent performance.

There are a few studies undertaken on the relationship between transformational leadership and organizational commitment. Arnold, Barling, and Kelloway (2001) conducted a study on the relationship between transformational leadership and effectiveness of teamwork. The results showed that transformational leadership had a significant relationship with trust, commitment, and team efficiency. Likewise, Yu, Leithwood, and Jantzi (2002) in a study on the relationship between transformational leadership and organizational commitment over the teachers in Hong Kong demonstrated that there was a positive and significant relationship between transformational leadership style and organizational commitment. To date, quite a few studies have investigated the relationship between transformational leadership and organizational commitment in schools and its impact on the organizational commitment of teachers. Therefore, the present study aimed at investigating the relationship between transformational leadership and organizational commitment of teachers in secondary schools of Germi.

\section{Conceptual Framework of the Study}

Transformational leadership paradigm has its root in the sixteenth century when Machiavelli conducted research on the King. Machiavelli studied the effect of traits and behaviors of the leaders in development of leadership theory inside the feudal structure of England. In his opinion a leader is the one who directs and provides support for others to achieve goals. 
The history of research on transformational leadership and Burns' activities dates back to 1978. Burns indicated that transformational leaders are insightful and encourage others to take unique actions. Following the Burns studies, Bass presented a model in 1985 that prescribed transactional leadership and transformational leadership, respectively for organizational sustainability and transformation situations. Bass and Avoilo (1996) developed a model and identified the dimensions of transformational leadership and transactional leadership, and even operationalized this model in the form of a questionnaire called the Multifactor Leadership Questionnaire.

Hersey and Blanchard (1969, 1977) defined the transformational leadership as the informed process of influence in the individuals or groups for making discontinuous change in the status quo and functions of the organization as a whole. In the same vein, Bass (1985) describes the transformational leaders as people who empower their subordinates and stimulate them to perform beyond expectations. Precisely speaking, transformational leaders prompt their subordinates to do what they have in their capacity.

Transformational leaders transform the organization through their words, actions, speech, and behaviors and have a lot of influence on their followers. When leaders increase their followers' zeal in their works, make them aware of the goals and missions and encourage them to think beyond individual interests, this type of leadership can be realized. Transformational leaders encourage their followers to view old issues from new perspectives and generate motivation in them to make effort beyond personal interests and goals and strive for major team, organizational, national, and global goals. These leaders, outlining the future vision, exert such an influence on their followers that they perceive the vision as their own and work toward achieving it. They have the ability to coordinate the employees, create coherence in the whole system, and direct the entire organization toward vision.

\section{Components of Transformational Leadership}

Transformational leadership requires four factors which have been identified as the main components of the theory, including firstly, idealized influence comprises behaviors such as building trust among people, and showing them respect, encouraging subordinates to identify and model their leaders' behaviors. Idealized influence can be explained with the statement "A leader is proud because his subordinates support him". Idealized influence is corresponding to the charisma of leaders which gives the subordinates the impression about the extraordinary features and capabilities of leader; secondly, inspirational motivation 
includes a variety of behaviors that encourage subordinates towards a common vision. This insight has been formed through the process of discussion and negotiation, and its emphasis is on the negative characteristics of status quo and positive features of future. Inspirational motivation can be introduced with the statement "A leader draws a picture of vision and yields to insights in the future"; thirdly, intellectual Stimulation is a kind of a behavior that is triggered the subordinates to make innovations regarding the current situations and the existing assumptions. Intellectual stimulus is introduced with the statement: "The leader is someone who looks at problems from different perspectives"; finally, individualized consideration is a kind of behavior that provides subordinates with the opportunity to put their capabilities and potentials into practice via training mentoring relationship development. According to individualized consideration, a leader is a person who devotes a lot of time into training and educating of his/her subordinates (Colquitt, Lepine, \& Wesson, 2010).

The results of the studies to date indicate that transformational leadership brings about decisive effects in organizations such as increasing organizational commitment and motivation of the subordinates. Generally, style of transformational leadership enhances efficacy of the leaders.

By and large, the historic principles and roots of a variety of leadership behaviors originate from sociology of charisma (Weber, 1946, 1947), charismatic leadership theory (House, 1997), and transformational leadership theory (Burns, 1978 \& Bass, 1985), are to a great extent associated with change-oriented behaviors (Pearce et al., 2003; Quinn , Faerman, Thompson, \& McGrath, 1990).

\section{Organizational Commitment}

In the early 1980s, the staffs' organizational commitment was one of the issues that drew the attention of many researchers and extensive research was conducted on it. Walton (1985), by his famous article entitled as "Commitment-Based Management" pulled other studies in this direction (Amirkabiri, Khodayari, Nazari, \& Moradi, 2007). Organizational commitment like other concepts has been defined in different ways. The most common method to deal with organizational commitment is to take organizational commitment as a kind of emotional attachment to organization. According to this approach, a person who is strongly committed finds his/her identity in the organization, involves in, merges into it, and enjoys being a member of an organization. Porter, Steers, Mowday, and Boulian (1974) define organizational commitment as accepting the values and involvements in an organization. 
According to them, there is a kind of motivation and desire to continue working in organizations, and accepting values of organizations as measurement criteria. The result of the study on the factors the affect job abandoning shows that resignation can be more accurately predicted by organizational commitment.

Burn (1978) has also uncovered other factors such as individual accountability, recurrence of work, opportunities for job promotion, availability of alternative career opportunities, age, background, gender, and satisfaction with principals as effective factors in organizational commitment (Hosseini \& Mehdizadeh Ashrafi, 2010).

On the other hand, organizational commitment refers to a mental state by which a person binds himself to an organization. Consequently, the risk of leaving organization reduces. Meyer and Allen (1991, as cited in Colquitt et al., 2010) have classified organizational commitment into the following three types, including affective commitment which denotes the emotional attachment of employees to organization, the development of their identity, and their involvement in the organization. In other words, an individual keeps working in an organization, because he/she voluntarily wants to do so; secondly, continuance commitment is a desire to stay in the organization in order to become aware of the costs of leaving. In other words, the individual stays in the organization since he/she needs it; and normative commitment which is people's propensity to stay in the organization as a result of a sense of obligation. In other words, a person keeps working in organization, since he/she is obliged to stay.

Therefore, organizational commitment is an attitude toward loyalty of employees to organizations and is an ongoing process that is determined by participation of individuals in organizational decision makings, their concern for the organization's success and well-being of individuals. On the other side, education and training organization in order to achieve its desirable goals i.e. educating and training of individuals, needs teachers who are active, sympathetic, and committed. Committed teachers are-responsible for actions performed, fulfill their duties in the best way, and increase the efficiency, effectiveness, and productivity of educational system.

\section{Research Question and Hypothesis}

The purpose of the study is to investigate the relationship between transformational leadership style and organizational commitment of secondary school teachers in Germi. In order to achieve the purpose of the study, the following research question was postulated: 
Is there a significant relationship between transformational leadership style and organizational commitment of secondary school teachers in Germi?

The main hypothesis of the research is:

There is a significant relationship between transformational leadership style and organizational commitment of secondary school teachers in Germi.

The sub-hypothesis of the research is:

There is a significant relationship between idealized influence, inspirational motivation, intellectual stimulation, and individual consideration and organizational commitment of secondary school teachers.

\section{Method}

This study examined the relationship between transformational leadership and organizational commitment of teachers. The design of the study was descriptive and correlational. The statistical population consisted of 400 secondary school teachers in Germi. From the original pool of participants, only 196 teachers were selected by the use of simple random sampling. The sample size was also determined by using Cochrane formula. To collect data, Multifactor Leadership Questionnaire of Bass (1985) and Porter's Organizational Commitment Questionnaire (1974) were used. The Multifactor Leadership Questionnaire had 36 items. This research tried to investigate the relationship between transformational leadership and organizational commitment of teachers; so the questions related to transactional leadership and non-interventionist leaders (neutral) were omitted from the list of questions, and 20 items about transformational leadership with responses scaled from 1 through 5 (5-point Likert scale) were employed. To measure teachers' organizational commitment, organizational commitment scale of Porter et al. (1974) was employed. The scale consisted of 15 items with responses anchored in 7 points (ranging from completely agree to completely disagree). The items of this questionnaire determined the extent to which each employee accepted the goals and values of the organization, wished to make an extraordinary attempt that contributes to the success of organization, and was interested in continuing his membership in the organization.

\section{Validity and Reliability of Research Instruments}

To determine the validity of Multifactor Leadership Questionnaire, in spite of those being utilized in the research studies conducted within and outside the country of Iran, the views 
and comments of specialists, academic researchers, and experts were also considered and the validity of the questionnaire was approved with respect to a consensus of opinions.

Twenty percent of all participants completed the questionnaire two times in a 15-day interval. By using Pearson correlation coefficient, the correlation between first and second scores for each individual was calculated. The coefficient was $80 \%$ indicating good reliability of the questionnaire. Moreover, to estimate the reliability of questionnaire, test-retest method was employed. To calculate the reliability, Cronbach's alpha coefficient was used. The value obtained by this method was 0.94 (94\%). Since Cronbach's alpha coefficient more than 70\% is acceptable, we can argue that the multifactor leadership questionnaire was in acceptable level of reliability.

The results concerning the validity and reliability of organizational commitment questionnaire estimated in different studies in Iran and other countries were reviewed as well. For instance, Mawody, Steers, Porter, and Porter (1979) reported a reliability of $90 \%$ and validity of $70 \%$. They reported reliability of $91 \%$ for experts sample and $89 \%$ for the typical white-collar professionals. Other researchers had reported the reliability coefficient of $90 \%$ for the questionnaire.

In the present study, based on the data gathered, the alpha reliability coefficient of the questionnaire was calculated to be $80 \%$. Overall, all the cases indicated appropriate and acceptable reliability and validity for the questionnaire.

\section{Results}

The relationship between transformational leadership style and organizational commitment of Germi school teachers was examined. In order to achieve the purpose of the study, the obtained data were analyzed and the results of the data analysis are presented.

Table 1

The Relationship between Transformational Leadership and Organizational Commitment of Secondary

School Teachers

\begin{tabular}{ccccc}
\hline Conclusion & $\begin{array}{c}\text { Correlation } \\
\text { Coefficient }\end{array}$ & $\begin{array}{c}\text { Level of } \\
\text { Significance }(\mathrm{P})\end{array}$ & Criterion Variable & Variable Predictor \\
\hline $\begin{array}{c}\text { Rejection of Null } \\
\text { Hypothesis }\end{array}$ & 0.33 & 0.00 & $\begin{array}{c}\text { Organizational } \\
\text { Commitment }\end{array}$ & $\begin{array}{c}\text { Transformational } \\
\text { Leadership }\end{array}$ \\
\hline
\end{tabular}

As Table 1 shows, the correlation coefficient value for transformational leadership and organizational commitment of high school teachers in Germi was 0.33, which is less than 0.01 based on $P$ value. Based on Table 1 , the significance value is less than the $P$ value, 
0.05. The correlation between variables is significant at $99 \%$ confidence level. Hence, the null hypothesis was rejected. Finally, it can be concluded that there is a significant relationship between the two variables of transformational leadership and organizational commitment of secondary school teachers in Germi.

Moreover, there was a significant relationship between idealized influence and organizational commitment of secondary school teachers.

Table 2

The Relationship between Idealized Influence and Organizational Commitment of Secondary School Teachers

\begin{tabular}{ccccc}
\hline Conclusion & Correlation Coefficient & Level of Significance $(\mathrm{P})$ & Criterion Variable & Variable Predictor \\
\hline $\begin{array}{c}\text { Rejection of Null } \\
\text { Hypothesis }\end{array}$ & 0.35 & 0.00 & $\begin{array}{c}\text { Organizational } \\
\text { Commitment }\end{array}$ & Idealized Influence \\
\hline
\end{tabular}

As Table 2 displays, the correlation coefficient for idealized influence and organizational commitment of high school teachers in Germi has value of 0.35 which is less than 0.01 based on $P$ value. The calculated level of significance is less than 0.05 , so the correlation between variables is significant and has $99 \%$ confidence level. It can be claimed that the research hypothesis is supported. Therefore, it can be argued that there is a significant relationship between idealized influence and organizational commitment of secondary school teachers in Germi. There was, also, a significant relationship between inspirational motivation and organizational commitment of secondary school teachers.

Table 3

The Relationship between Inspirational Motivation and Organizational Commitment of Secondary School Teachers

\begin{tabular}{ccccc}
\hline Conclusion & $\begin{array}{c}\text { Correlation } \\
\text { Coefficient }\end{array}$ & $\begin{array}{c}\text { Level of } \\
\text { Significance (P) }\end{array}$ & Criterion Variable & Variable Predictor \\
\hline Rejection of Null Hypothesis & 0.30 & 0.00 & $\begin{array}{c}\text { Organizational } \\
\text { Commitment }\end{array}$ & $\begin{array}{c}\text { Inspirational } \\
\text { Motivation }\end{array}$ \\
\hline
\end{tabular}

As Table 3 illustrates, the correlation coefficient between idealized influence and organizational commitment of high school teachers in Germi is 0.30. Since the calculated level of significance is less than 0.05 , the correlation between variables is significant and has 99\% confidence level. So, the null hypothesis is rejected and the research hypothesis is confirmed. Hence it can be argued that there is a significant relationship between idealized influence and organizational commitment of secondary school teachers in Germi. There was also a significant relationship between intellectual stimulation and organizational commitment of secondary school teachers. 
Table 4

The Relationship between Intellectual Stimulation and Organizational Commitment of Secondary School Teachers

\begin{tabular}{cccc}
\hline Conclusion & $\begin{array}{c}\text { Correlation } \\
\text { Coefficient }\end{array}$ & Level of Significance (P) & Criterion Variable \\
\hline Rejection of Null Hypothesis & 0.19 & 0.00 & $\begin{array}{c}\text { Organizational } \\
\text { Commitment }\end{array}$ \\
\hline
\end{tabular}

As Table 4 shows, the correlation coefficient between intellectual stimulation and organizational commitment of secondary school teachers in Germi is 0.19 . Regarding $P$ value, it is less than 0.01 . Since the calculated level of significance is less than 0.05 , the correlation between variables is significant and has $99 \%$ confidence level, which results in rejecting the null hypothesis. Arguably, there was a significant relationship between the two variables of intellectual stimulation and organizational commitment of secondary school teachers in Germi. Finally, there was a significant relationship between individual consideration and organizational commitment of secondary school teachers.

Table 5

The Relationship between Individual Consideration and Organizational Commitment of Secondary School Teachers

\begin{tabular}{ccccc}
\hline Conclusion & $\begin{array}{c}\text { Correlation } \\
\text { Coefficient }\end{array}$ & $\begin{array}{c}\text { Level of } \\
\text { Significance (P) }\end{array}$ & Criterion Variable & Variable Predictor \\
\hline Rejection of Null Hypothesis & 0.20 & 0.00 & $\begin{array}{c}\text { Organizational } \\
\text { Commitment }\end{array}$ & $\begin{array}{c}\text { Individual } \\
\text { Consideration }\end{array}$ \\
\hline
\end{tabular}

According to Table 5, the correlation coefficient between individual consideration and organizational commitment of secondary school teachers in Germi is 0.20. Since the calculated level of significance is less than 0.05 , the correlation between variables is significant; consequently, the null hypothesis is rejected. In sum, it can be concluded that there is a significant relationship between individual consideration and organizational commitment of secondary school teachers in Germi. Also to predict organizational commitment of teachers through transformational leadership, stepwise Multiple Regression Method was used. In this method, it is not the investigator that enters data related to the predictive variables, instead it is done automatically according to the correlation coefficient, i.e., in the case of obtaining the criterion variable they will remain in the analysis process, otherwise, they will be eliminated. Finally, idealized influence, personal consideration, and intellectual stimulation developed the criterion value and were included; however, inspirational motivation variable was excluded from the regression. 
Table 6

Stepwise Regression Results

\begin{tabular}{ccc}
\hline & Multiple Correlation Coefficient R & Model \\
\hline 0.12 & 0.35 \\
0.14 & 0.37 \\
0.18 & 0.42 & 2 \\
\hline$-\quad$ Predictor variables: constant coefficient, idealized influence & 3 \\
- $\quad$ Predictor variables: constant coefficient, idealized influence, individual consideration & \\
\hline & Predictor variables: constant coefficient: idealized influence, individual consideration and intellectual stimulation
\end{tabular}

The result of stepwise regression analysis indicated that three components of transformational leadership, namely idealized influence, individual considerations, and intellectual stimulation are considered as predictor variables in secondary school teachers of Germi to fulfill the criteria being included in final regression equation, and to explain the change of organization's commitment in Germi (criterion variables). As Table 6 represents, the intensity of the relationship between organizational commitment and idealized influence in secondary school teachers of Germi is 0.35 . Having included individual consideration and intellectual stimulation, this amount can vary and increase to 0.37 and 0.42 respectively.

The coefficient of determination column in Table 6 indicates that 0.18 of change in organizational commitment of secondary school teachers in Germi can be predicted by three variables of idealized influence, individual consideration, and intellectual stimulation. Besides, due to the affecting amount of the three variables mentioned above on organizational commitment, the effect of inspirational motivation on organizational commitment of secondary school teachers in Germi is neutralized. Additionally, analysis of variance in Table 7 also demonstrates that the regression is highly significant and suggests that there is a linear relationship between variables.

Table 7

Variance Analysis

\begin{tabular}{cc|c}
\hline Level of Significance & F & Model \\
\hline 000.0 & 27.12 & 1 \\
000.0 & 15.73 & 2 \\
000.0 & 14.26 & 3 \\
\hline
\end{tabular}

Table 8

Results of Regression Analysis

\begin{tabular}{ccccl}
\hline Level of Significance & T & Beta & B & Parameter \\
\hline 000.0 & 10.63 & 0.37 & 16.43 & Constant Coefficient, \\
000.0 & 3.57 & 0.35 & 0.28 & Idealized Influence, \\
0.00 & 3.31 & -0.3 & 0.42 & Individual Consideration \\
0.00 & -3.14 & & -0.43 & Intellectual Stimulation \\
\hline
\end{tabular}

Criterion variables: organizational commitment of secondary school teachers in Germi 
Table 8 displays the regression coefficients and t-test for testing these coefficients and level of significance of each one. And, column B also indicates that as the idealized influence changes one standard deviation, the organizational commitment of secondary school teachers in Germi changes $0.37 \mathrm{SD}$, as a consequence of it. Similarly, for every $1 \mathrm{SD}$ change in individual consideration and intellectual stimulation, 0.35, and - 0.36 SD change occurs in the organizational commitment of secondary school teachers in Germi. Accordingly, the variable of idealized influence has the highest degree of effect on organizational commitment of secondary school teachers in Germi.

\section{Discussion and Conclusion}

Today, as organizations are incrementally faced with dynamic and changing situations in order to survive, they have to adjust themselves to environmental changes. Having taken the accelerating pace of change and scientific, technological, social, cultural, and educational developments into account, the organizations are considered successful and efficient. Also beside keeping pace with modern development of society, they are able to predict the future shifts, and lead them toward a direction that brings about desirable changes and creates a better future. As Toffler (1970) puts "only by creatively using changes for directing themselves, one can remain safe from future shock damages and achieve a better and more human future".

Likewise, educational organizations undergo these changes as well. They have no choice other than conforming to these changes, otherwise they cannot survive. The implication of transformational leaders for people in many countries, especially in the West, is the leaders who are competent and efficient. Such leaders, because of having distinctive and unique characteristics, great power of influence, grand vision, and remarkable human and conceptual skills, can manage the crisis which schools in the present era suffer. To achieve organizational goals, managers, using their characteristics, influence teachers and create high interest and incentive in them for making optimal use of their talents and abilities.

In the present study the relationship between components of transformational leadership and organizational commitment was examined. The obtained results revealed a positive and meaningful relationship between all components of transformational leadership and organizational commitment. This finding suggests that the more dominant transformational leadership style is in the management strategies of managers and leaders, the greater the organizational commitment of staff will be. In contrast, when transformational leadership is 
less used in managing, the organizational commitment of staff is used so. Besides, when the schools' managers are of great personal characteristics, they lend an ear to individual comments, attend to high-level needs of teachers, give them mental stimulation, provide a situation where teachers develop a sense of attachment to education and school, and make them strive for the success of school and continue their membership in it.

Overall, the findings of the present investigation was in line with the findings of previous studies conducted by Amir Kabiri et al. (2007); Arnold et al. (2001); Bass (1997); Fan Chen (2006); Geijsel, Sleegers, Lithwood, and Jantzi (2002); Javdani (2011); Leithwood and Jantzi (1992); Nikolina (2003); Pillai and Willims (2004); and Yu, Leithwood, and Jantzi (2002). And, in brief, the results of the regression analysis showed that among all the components of transformational leadership, idealized influence had the greatest effect on organizational commitment of teachers.

\section{References}

Amirkabiri, A., Khodayari, E., Nazari, F., \& Moradi, M. (2007). Survey of relationship between transformational and transactional leadership and personnels' organizational commitment. Management Culture Journal, 4(4), 117-142.

Arnold, K. A., Barling, J., \& Kelloway, E. K. (2001). Transformational leadership or the iron cage: Which predicts trust, commitment and team? Leadership and Organization Development Journal, 22(7), 315-320.

Bass, B. M. (1985). Leadership and performance beyond expectations. New York: Free Press.

Bass, B. M. (1997). Does the transactional-transformational leadership paradigm transcend organizational and national borders? American Psychologist, 52(2), 130-139.

Bass, B. M., \& Avolio, B. J. (1992). Developing transformational leadership: In 1992 and beyond. Journal of European

Industrial Training, 14(5), 21-27.

Bass, B. M., \& Avolio, B. J. (1996). The transformational and transactional leadership of men and women. Applied Psychology: An International Review, 45, 5-34.

Burns, J. M. (1978). Leadership. New York: Harper \& Row.

Chen. M. F. (2007). The relationship among transformational leadership, organizational commitment and organizational citizenship behavior (Unpublished doctoral dissertation). National Sun Yat-sen University, Kaohsiung, Taiwan.

Colquitt, J., Lepine, J. A., \& Wesson, M. J. (2010). Organizational behavior: Essentials for improving performance and commitment. Boston: McGraw-Hill Irwin.

Geijsel, F., Sleegers, P., Leithwood, K.., \& Jantzi, D. (2003). Transformational leadership effects on teachers' commitment and effort toward school reform. Journal of Educational Administration, 41(3), 228-256.

Hersey, P., \& Blanchard, K. H. (1969). Life cycle theory of leadership. Training and Development Journal, 23, 26-34.

Hersey, P., \& Blanchard, K. H. (1977). Management of organizational behavior: Utilizing human resources (4 ${ }^{\text {th }}$ ed.). Englewood Cliffs, NJ: Prentice Hall.

Hosseini, S. M., \& Mehdizadeh Ashrafi. A. (2010). The study of efficiency factors on organizational commitment. Pazhoheshgar Quarterly, 7(18), 9-16.

Javdani, M. (2011). Examination of the relationship between transformational/ transactional leadership and organizational commitment of teachers, foundations of Education. Research Bulletin of Ferdowsi University (FUM), 1(1), 143-158.

Leithwood, K. A., \& Jantzi, D. (1991). Transformational leadership: How principals can help reform school cultures. School Effective and School Improvement, 1(3), 249-281. 
Meyer, J. P., \& Allen, N. J. (1991). A three component conceptualization of organizational commitment. Human Resource Management Review.,1(1), 61-89.

Mowday, R. T., Steers, R. M., \& Porter, L. W. (1979). The measurement of organizational commitment. Journal of Vocational Behavior, 14, 224-247.

Nguni, S., Sleegers. P., \& Denessen, E. (2002). Transformational and transactional leadership effects on teachers Job satisfaction, organizational commitment, and organizational citizenship behavior in primacy schools: The Tanzanian case. School Effectiveness School Improvement, 17(2), 145-177.

Nicolina, A. (2003). Faculty and chair perspectives on leadership and its impacts on Departmental outcomes (Master's thesis). Arts McGill University, Montreal, Canada.

Pearce, J. (2003) Social Enterprise in Anytown. London: Calouste Gulbenkian Foundation.

Pearce, C. L., Sims, H. P., Cox, J. F., Ball, G., Schnell, E., Smith, K. A. , \& Trevino, L. (2003). Transactors, transformers and beyond: A multi-method development of a theoretical typology of leadership. Journal of Management Development, 22(4), 273-307.

Pillai, R., \& Williams, E. A. (2004). Transformational leadership, self-efficacy, group cohesiveness, commitment, and performance. Journal of Organizational Change Management, 17(2), 144-159.

Porter, L.W., Steers, R. M., Mowday, R. T., \& Boulian, P. V. (1974). Organizational commitment, job satisfaction, and turnover among psychiatric technicians. Journal of Applied Psychology, 59, 603-609.

Quinn, R., Faerman, S., Thompson, M., \& McGrath, M., (1990). Becoming a master manager: A competency framework.

USA: John Wiley and Sons.

Robbins, S. (1998). Organizational behavior: Concepts, controversies and applications ( ${ }^{\text {th }}$ ed.). New Jersey: Prentice Hall.

Robbins, S. P. (2005). Essentials of organizational behavior ( $8^{\text {th }}$ ed.). Upper Saddle River, N J: Pearson Prentice Hall.

Schermerhorn, J. (1997). Situational leadership: Conversations with Paul Hersey. Mid-American Journal of Business, 12(2), 5-11.

Stogdill, R. M. (1974). Handbook of leadership: A survey of theory and research. New York: Free Press.

Toffler, A. (1970). Future shock. New York: Random House.

Weber, M. (1946). From Max Weber: Essays in sociology (H. H. Gerth \& C. W. Mills, Trans). New York: Oxford University Press.

Weber, M. (1947). The theory of social and economical organizational (A. M. Henderson \& T. Parsons, Trans). NY, US: Free Press.

Yu, H., Leithwood, K., \& Jantzi, D. (2002). The effects of transformational leadership on teachers' commitment to change in Hong Kong. Journal of Educational Administration, 40(4), 368-389.

Yukl, G. (2003). Tridimensional leadership theory: A roadmap for flexible, adaptive leaders. In R. J. Burke \& C. Cooper (Eds.), Leading in turbulent times (pp.75-91). London: Blackwell. 